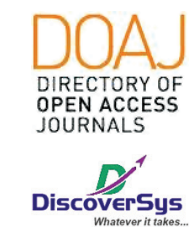

Published by DiscoverSys

\title{
Pemberian ekstrak etanol Cordyceps militaris dapat menurunkan kadar glukosa darah dan menghambat penurunan massa sel beta pankreas pada tikus diabetes mellitus yang diinduksi dengan Streptozotocin dan Nikotinamid
}

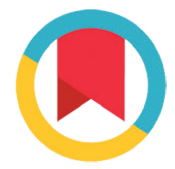

CrossMark

\author{
Jopy Wikana ${ }^{1 *}$
}

\section{ABSTRACT}

Background: The antioxidant and anti-inflammatory effects of Cordyceps militaris extracts can neutralize the increased production of Reactive 0xygen Species (ROS) due to hyperglycemia conditions, as well as neutralize N0 produced through inducible Nitric Oxide Synthase (iNOS). Thus, the antioxidant effects of C. militaris extract are expected to decrease DNA damage and ER stress leading to intrinsic apoptosis of pancreatic beta cells. Another positive effect of $C$. militaris which is expected to suppress glucotoxicity is its hypoglycemic effect.

Methods: The design of this study was Randomized Post-test Only Control Group Design. The study was conducted on mice divided into three groups: negative control group (DM + placebo), treatment 1 group and treatment 2 group.

Results: Based on study on 15 rats, each 5 rats per group, it was found that the mean blood glucose level in control group was $399,20 \pm 28,07 \mathrm{mg} / \mathrm{dl}$, mean of blood glucose level of treatment
1 group (extraction $50 \%$ ethanol C. militaris) was $198.60 \pm 30.42 \mathrm{mg} / \mathrm{dl}$, and, the mean blood glucose levels of the treatment 2 group (extract ethanol C. militaris $100 \%$ ) was $141.00 \pm 17.03 \mathrm{mg} / \mathrm{dl}$. With One Way ANOVA test found that $p$-value $=0,001$. Immunohistochemical examination result shows that beta cell mass is more prominent in either treatment group 1 and treatment group 2 compare to the control group.

Conclusions: There were significant differences in blood glucose levels of mice given extracted ethanol C. militaris compare to the control group. It is further known that ethanol extract of $C$. militaris can decrease blood glucose level by $50,25 \%$ at $50 \%$ concentration and $64,68 \%$ at $100 \%$ concentration. Immunohistochemical examination result shows that ethanol extract of $C$. militaris seem could inhibit the decrease of beta cell mass in diabetic mice induced by STZ and NA especially at $100 \%$ concentration.
'S3 Kedokteran

Pasca Sarjana Universitas Udayana

${ }^{*}$ Correspondence to:

Jopy Wikana, S3 Kedokteran Pasca Sarjana Universitas Udayana jopywk@gmail.com

Received: 2018-02-27 Accepted: 2018-03-5 Published: 2018-05-1

Keywords: Cordyceps militaris, beta cells, type 2 diabetes, pancreas

Cite This Article: Wikana, J. 2018. Pemberian ekstrak etanol Cordyceps militaris dapat menurunkan kadar glukosa darah dan menghambat penurunan massa sel beta pankreas pada tikus diabetes mellitus yang diinduksi dengan Streptozotocin dan Nikotinamid. Intisari Sains Medis 9(2): 124-129. D0l: 10.1556/ism.v9i2.174

\section{ABSTRAK}

Latar belakang: Efek antioksidan dan antiinflamasi dari ekstraks Cordyceps militaris (C. militaris) mampu menetralisir peningkatan produksi Reactive Oxygen Species (ROS) akibat kondisi hiperglikemia, dan juga menetralisir N0 yang diproduksi melalui inducible Nitric Oxide Synthase (iNOS). Dengan demikian, efek antioksidan dari ekstraks C. militaris diharapkan mampu menurunkan kerusakan DNA dan ER stress yang mengarah pada apoptosis intrinsik sel beta pankreas. Efek positif lain dari C. militaris yang diharapkan mampu menekan glukotoksisitas adalah efek hipoglikemiknya.

Metode: Desain penelitian ini adalah Randomized Post-test Only Control Group Design. Penelitian dilakukan terhadap tikus yang dibagi dalam 3 kelompok yaitu kelompok kontrol negatif (DM + placebo), kelompok perlakuan 1 dan kelompok perlakuan 2.

Hasil: Berdasarkan hasil penelitian pendahuluan pada 15 ekor tikus, yaitu masing-masing 5 ekor per kelompok, didapatkan bahwa rerata kadar glukosa darah pada kelompok kontrol adalah 399,20 \pm 28,07 mg/dl, rerata kadar glukosa darah kelompok perlakuan 1 (ekstraks etanol C. militaris 50\%) adalah 198,60 $\pm 30,42 \mathrm{mg} / \mathrm{dl}$, dan, rerata kadar glukosa darah kelompok perlakuan 2 (ekstraks etanol C. militaris 100\%) adalah $141,00 \pm 17,03 \mathrm{mg} / \mathrm{dl}$. Dengan uji One Way Anova didapatkan bahwa nilai $p=0,001$. Hasil pemeriksaan imunohistokimia memperlihatkan bahwa jumlah sel beta pankreas baik pada kelompok perlakuan 1 maupun kelompok perlakuan 2 lebih banyak dari pada kelompok kontrol. Kesimpulan: Terdapat perbedaan secara bermakna pada kadar glukosa darah tikus yang diberi ekstraks etanol C. militaris dibandingkan dengan kelompok kontrol. Lebih lanjut diketahui bahwa pemberian ekstraks etanol Cordyceps militaris dapat menurunkan kadar glukosa darah sebesar 50,25\% pada konsentrasi 50\% dan $64,68 \%$ pada konsentrasi $100 \%$. Hasil pemeriksaan imunohistokimia menunjukkan bahwa pemberian ekstraks etanol C. militaris tampaknya dapat menghambat penurunan sel beta pankreas pada tikus DM yang diinduksi dengan STZ dan NA , terutama pada konsentrasi $100 \%$. 
Kata kunci: C. militaris, sel beta pankreas, DM tipe 2

Cite Pasal Ini: Wikana, J. 2018. Pemberian ekstrak etanol Cordyceps militaris dapat menurunkan kadar glukosa darah dan menghambat penurunan massa sel beta pankreas pada tikus diabetes mellitus yang diinduksi dengan Streptozotocin dan Nikotinamid. Intisari Sains Medis 9(2): 124-129. D0l: 10.1556/ism.v9i2.174

\section{PENDAHULUAN}

Diabetes mellitus tipe 2 (DMT2) merupakan faktor risiko utama bagi terjadinya penyakit kardiovaskuler, stroke, kanker, dan lain-lain. Dengan demikian, penting sekali untuk lebih memahami penyakit DMT2 ini agar dapat dilakukan pencegahan dan pengobatan yang mendasar guna mencegah terjadinya berbagai komplikasi dari DMT2 sesuai dengan kaidah dari Anti-Aging Medicine (AAM).

Meskipun patofisiologi DMT2 didasari oleh adanya resisten insulin (RI), banyak dijumpai individu dengan RI tidak menderita DMT2. Hal ini bisa terjadi karena sel beta pankreas masih mampu melakukan kompensasi dengan peningkatan pelepasan insulin dan atau massa sel beta untuk mengatasi kerja insulin yang kurang efektif tersebut, sehingga terjadi hiperinsulinemia. ${ }^{1,2}$

Karena itu pada DMT2, selain terjadi RI yang kronis, terdapat pula penurunan progresif dalam fungsi (disfungsi) sel beta pankreas sehingga tidak mampu mengkompensasi turunnya sensitivitas insulin lebih lanjut. ${ }^{1,3} \mathrm{Di}$ samping itu, diketahui pula bahwa pada DMT2 terdapat hiperglukagonemia akibat disfungsi sel alfa pankreas. ${ }^{4}$

Banyak faktor yang terlibat dalam terjadinya RI seperti berbagai toksin dalam lingkungan, glycemic load, obesitas, stres emosional, infeksi, diet, gaya hidup dan faktor genetik. ${ }^{5}$ Faktor-faktor tersebut akan menyebabkan terjadinya inflamasi kronis derajat rendah (chronic low-grade inflammation) dan stres oksidatif. Jadi, RI pada DMT2 merupakan salah satu respons dari adanya inflamasi sistemik kronik yang ditandai dengan peningkatan sekresi mediator-mediator pro-inflamasi seperti tumor necrosis factor- $\alpha$ (TNF- $\alpha$ ), interleukin-6 (IL-6), dan Interleukin- $1 \beta$ (IL-1 $\beta){ }^{5}$

Saat ini pendekatan farmakologis DMT2 secara konvensional dengan cara bertahap (stepwise manner) dianggap kurang tepat karena tidak menyasar kepada patofisiologi dasar dari DMT2 yang heterogen di mana terdapat gangguan dari sekresi insulin, baik karena efek glukotoksisitas atau pengurangan massa sel beta pankreas, dan kerja insulin yang terjadi sejak awal perjalanan penyakit, gangguan dari sel alfa dan keterlibatan dari hormon-hormon seperti inkretin dan lainlain. Alasan tersebut mendorong adanya pendekatan terapi yang lebih intensif dan agresif untuk mencapai dan mempertahankan kadar glukosa darah sesuai dengan target yang direncanakan, dengan tujuan untuk mengurangi risiko komplikasi mikro dan makrovaskular. Dalam hal ini pemakaian insulin dapat dipertimbangkan sejak awal pada pasien dengan gejala dan hiperglikemia yang berat. Bahkan dengan adanya obat-obat baru seperti incretin mimetics dan dipeptidyl peptidase-4 (DPP-4) inhibitor, kini pengobatan DMT2 juga sudah menuju ke arah perbaikan fungsi sel beta dan alfa pankreas, sehingga dapat memperbaiki kondisi hiperglikemianya serta mungkin mempunyai potensi untuk meningkatkan sel beta pankreas dengan mengurangi proses apoptosis dalam jangka panjang. ${ }^{6,7}$

Salah satu pengobatan herbal bagi penyakit DMT2 adalah digunakannya jamur obat (medicinal mushrooms). Secara tradisional, beberapa jenis jamur obat memang telah digunakan di berbagai negara sejak ratusan tahun yang lalu untuk mempertahankan kesehatan, pencegahan dan pengobatan berbagai penyakit termasuk DMT2 dan penyakit kardiovaskular. ${ }^{8,9}$ Namun demikian, seperti halnya dengan obat-obatan herbal lainnya, data empiris yang menunjukkan efektivitas jamur obat tersebut sampai saat ini masih sangat terbatas dan memerlukan penelitian lebih lanjut. Saat ini diperkirakan terdapat lebih dari 2500 varietas jamur di dunia dan lebih dari 10 juta metrik ton jamur obat yang dihasilkan di berbagai negara pada tahun 2009. Karena itu akhir-akhir ini jamur telah menarik perhatian khusus dari para peneliti medis dan farmasi sebagai suatu sumber yang kaya akan senyawa-senyawa bioaktif. Apalagi perkembangan teknologi analisis kimiawi dewasa ini telah memungkinkan diisolasinya bahan-bahan aktif dalam obat-obatan modern yang disintesis sebagai hasil dari penelitian-penelitian obat-obatan herbal termasuk jamur obat. Kini obat-obatan herbal mempunyai peran yang penting dalam perkembangan kedokteran modern dan akan tetap digunakan dalam bentuk orisinilnya. ${ }^{10}$

Cordyceps (Caterpillar fungus) merupakan salah satu jamur obat yang terkenal dan banyak dipakai untuk pengobatan berbagai penyakit pada pengobatan tradisional Tiongkok (Traditional Chinese Medicine, TCM) di mana eksistensinya bahkan sudah dikenal sejak 2000 tahun sebelum masehi. ${ }^{10}$ Cordyceps adalah jenis jamur yang hidup sebagai parasit dalam tubuh larva atau pupa insekta seperti lepidopteron (entomopathogenic/entomogenous 
fungus) di mana pada saat musim dingin tetap sebagai suatu cacing dan di saat musim panas bertransformasi menjadi suatu jamur. Karena itu disebut juga sebagai "winter worm and summer grass" (Dong-Chong-Xia-Cao dalam bahasa mandarin). Terdapat lebih dari 400 jenis jamur Cordyceps di mana yang terkenal adalah Cordyceps sinensis (C. sinensis) dan Cordyceps militaris (C. militaris). ${ }^{10-12}$

C. militaris merupakan salah satu obat tradisional Tiongkok yang sangat penting, yang telah digunakan secara luas sebagai obat alami (crude drug), tonikum untuk panjang umur (longevity), ketahanan fisik (endurance) dan vitalitas (vitality) sejak ribuan tahun lalu. ${ }^{12}$ Memang mayoritas pemakaian obat-obatan herbal, termasuk C. militaris, seringkali hanya berdasarkan pengalaman dan kepercayaan di masyarakat tanpa didasari oleh studi ilmiah yang kuat. Namun akhir-akhir ini dengan kemajuan di bidang uji laboratorium, semakin banyak pula penelitian ilmiah bagi obat-obat herbal termasuk C. militaris. Berbagai penelitian menunjukkan bahwa ektraks C. militaris memiliki banyak efek farmakologis seperti imunomodulator, antikanker/tumor, antimetastatik, antiinflamasi, antioksidan, antimikrobial (bakteri, virus, jamur, parasit), steroidogenik, anti-fatigue, antistres, efek hipoglikemik/anti-diabetik, hipolipidemik, efek hipotensif dan vaso relaksan, liver protektif, renoprotektif, pneumoprotektif, neuroprotektif dan anti-aging. Karena itu pengembangan C. militaris sebagai salah satu obat herbal akan sangat penting dan bermanfaat bagi kesejahteraan manusia. . $^{9-12}$

Efek antioksidan dan antiinflamasi dari ekstraks C. militaris mampu menetralisir peningkatan produksi Reactive Oxygen Species (ROS) akibat kondisi hiperglikemia, dan juga menetralisir NO yang diproduksi melalui inducible Nitric Oxide Synthase (iNOS). Dengan demikian, efek antioksidan dari ekstraks $C$. militaris diharapkan mampu menurunkan kerusakan DNA dan ER stress yang mengarah pada apoptosis intrinsik sel beta pankreas. Efek positif lain dari C. militaris yang diharapkan mampu menekan glukotoksisitas adalah efek hipoglikemiknya.

Beberapa studi telah berhasil mengisolasi cordycepin, zat bioaktif dalam C. militaris yang dapat berfungsi sebagai antiinflamasi, dan polisakarida yang berperan sebagai antioksidan..$^{13}$ Oleh karena itu, penulis ingin meneliti lebih jauh mengenai efek ekstraks C. militaris terhadap sel beta pankreas pada tikus DM yang diinduksi dengan Streptozotocin (STZ) dan Nicotinamide (NA).

\section{METODE}

Penelitian ini menggunakan pendekatan deskripti Desain penelitian ini adalah Randomized Posttest Only Control Group. ${ }^{14}$ Penelitian dilakukan terhadap tikus yang dibagi dalam 3 kelompok yaitu kelompok kontrol negatif (DM + placebo), kelompok perlakuan 1 dan kelompok perlakuan 2. Tempat dilakukan penelitian ini di Fakultas Kedokteran Universitas Udayana Denpasar, Bali dan waktu penelitian dari September - Desember 2014. Populasi dalam penelitian eksperimental ini adalah 15 ekor tikus jantan dewasa galur Wistar. Untuk penelitian digunakan sampel 5 ekor tikus per kelompok, dan diadaptasikan di laboratoriun Animal Unit selama 2 minggu dengan diberikan makan dan minum ad libitum.

Tikus dibagi menjadi 3 kelompok. Kelompok 1 adalah kelompok tikus yang dibuat DM dan menerima plasebo. Kelompok 2 adalah kelompok tikus yang dibuat DM dan menerima perlakuan dengan ekstraks etanol C. militaris konsentrasi $50 \%$. Kelompok 3 adalah kelompok tikus yang dibuat DM dan menerima perlakuan dengan ekstraks etanol C. militaris konsentrasi $100 \%$. Semua kelompok tikus dipuasakan selama 18 jam. Siapkan semua bahan yang diperlukan untuk membuat tikus DM yaitu Nicotinamide (NA) dan Streptozotocin (STZ). Protokol pembuatan tikus DM sesuai dengan protokol yang telah dilakukan oleh Szkudelski (2012). Setelah 18 jam, tikus pada kelompok 1 sampai dengan 3 diberikan Nicotinamide (NA) dengan dosis $230 \mathrm{mg} / \mathrm{kg}$ berat badan secara intraperitoneal (IP). Lima belas menit kemudian diberikan STZ dengan dosis $65 \mathrm{mg} / \mathrm{kg}$ berat badan. Hari ke 10 kelompok tikus yang dibuat DM diharapkan sudah mengalami hiperglikemia atau DM sudah muncul. Hal ini diketahui dengan melakukan pemeriksaan glukosa darah. Kelompok kontrol negatif diberi akuades per oral. Kelompok perlakuan 1 diberi $1 \mathrm{cc}$ ekstraks etanol C. militaris dengan kadar $50 \%$ per oral. Kelompok perlakuan 2 diberi 1c ekstraks etanol C. militaris dengan kadar $100 \%$ per oral. Perlakuan diberikan selama 4 minggu. Setelah perlakuan semua sampel diambil darah untuk pemeriksaan gula darah. Kemudian dilanjutkan dengan pengambilan sampel pankreas untuk memeriksa massa sel beta pankreas.

Data yang diperoleh penelitian ini dianalisis dengan menggunakan Program SPSS 16.0 for Windows.Analisisdeskriptifdisajikandengannarasi, tabel dan grafik meliputi umur tikus, berat badan tikus. Uji normalitas data dengan uji Shapiro-Wilk 
karena data pada masing-masing kelompok $<30$ ekor. Data dinyatakan berdistribusi normal jika nilai $\mathrm{p}>0,05$. Uji homogenitas data dengan uji Lavene's Test untuk mengetahui variasi data antar kelompok perlakuan. Data antar kelompok dinyatakan homogen jika nilai $p>0,05$. Jika data berdistribusi normal dan homogen maka digunakan uji One Way Anova. Jika data tidak berdistribusi normal atau tidak homogen maka digunakan uji Kruskal-Wallis. Analisis data menggunakan tingkat kepercayaan $95 \%(\alpha=0,05)$.

\section{HASIL}

\section{Hasil pengukuran gula darah pada kelompok} hewan coba kontrol dan perlakuan

Berdasarkan hasil penelitian pendahuluan pada 15 ekor tikus, yaitu masing-masing 5 ekor per kelompok, didapatkan bahwa rerata kadar glukosa darah pada kelompok kontrol adalah 399,20 $\pm 28,07 \mathrm{mg} / \mathrm{dl}$,

Tabel 1 Hasil pengukuran gula darah pada kelompok hewan coba kontrol dan perlakuan

Hasil Pemeriksaan

\begin{tabular}{lcc}
\cline { 2 - 3 } Kode Sampel & Glukosa & Satuan \\
\hline K. 1 & 466 & $\mathrm{mg} / \mathrm{dl}$ \\
K. 2 & 372 & $\mathrm{mg} / \mathrm{dl}$ \\
K. 3 & 398 & $\mathrm{mg} / \mathrm{dl}$ \\
K. 4 & 395 & $\mathrm{mg} / \mathrm{dl}$ \\
K. 5 & 385 & $\mathrm{mg} / \mathrm{dl}$ \\
PI. 1 & 199 & $\mathrm{mg} / \mathrm{dl}$ \\
PI. 2 & 185 & $\mathrm{mg} / \mathrm{dl}$ \\
PI. 3 & 171 & $\mathrm{mg} / \mathrm{dl}$ \\
PI. 4 & 188 & $\mathrm{mg} / \mathrm{dl}$ \\
PI. 5 & 250 & $\mathrm{mg} / \mathrm{dl}$ \\
PII. 1 & 121 & $\mathrm{mg} / \mathrm{dl}$ \\
PII. 2 & 168 & $\mathrm{mg} / \mathrm{dl}$ \\
PII. 3 & 140 & $\mathrm{mg} / \mathrm{dl}$ \\
PII. 4 & 135 & $\mathrm{mg} / \mathrm{dl}$ \\
PII. 5 & 141 & $\mathrm{mg} / \mathrm{dl}$ \\
\hline
\end{tabular}

rerata kadar glukosa darah kelompok perlakuan 1 (ekstraks etanol C. militaris 50\%) adalah $198,60 \pm 30,42 \mathrm{mg} / \mathrm{dl}$, dan, rerata kadar glukosa darah kelompok perlakuan 2 (ekstraks etanol C. militaris $100 \%$ ) adalah $141,00 \pm 17,03 \mathrm{mg} / \mathrm{dl}$. Dengan uji One Way Anova didapatkan bahwa nilai $\mathrm{p}=0,001$. Hal ini menunjukkan bahwa terdapat perbedaan secara bermakna kadar glukosa darah sesudah diberikan ekstraks etanol C. militaris. Lebih lanjut diketahui bahwa pemberian ekstraks etanol C. militaris dapat menurunkan kadar glukosa darah sebesar $50,25 \%$ pada konsentrasi $50 \%$ dan $64,68 \%$ pada konsentrasi $100 \%$.

\section{Hasil pemeriksaan massa sel beta dengan menggunakan metode imunohistokimia}

Prosedur pembuatan preparat dengan metode imunohistokimia adalah sebagai berikut: Jaringan pankreas difiksasi dengan buffered formalin, diproses dengan tissue processor, dan dibuat sedian blok parafin. Jaringan pankreas dalam sedian blok parafin kemudian dipotong dengan ketebalan 4 mikron di atas glas obyek yang dilapisi dengan poly-L-lysine. Jaringan kemudian didepafinasi dengan xylol $2 \times 5$ menit dan klarifikasi dengan alkohol absolut $2 \times 5$ menit. Antigen dalam jaringan kemudian dipanaskan dalam buffer sitrat pada suhu $90^{\circ} \mathrm{C}$ selama 20 menit menggunakan microwave oven. Jaringan digenangi dengan $3 \% \mathrm{H} 2 \mathrm{O} 2$, selama 20 menit dan dicuci dengan PBS sebanyak $2 \times 3$ menit. Antibodi anti-insulin human ditambah dan diinkubasi pada suhu kamar selama 1 jam, dicuci dengan $\mathrm{PBS} \mathrm{pH}$ 7,4 dan digenangi dengan rabbit antimouse IgG-biotin (Dako; USA) selama 30 menit pada suhu kamar. Kemudian dicuci lagi seperti di atas, dan digenangi dengan streptavidin HRP (Dako, USA) selama 20 menit pada suhu kamar. Jaringan kemudian dicelupkan selama 10 menit ke dalam larutan DAB (DAKO USA, diaminobenzidine $0.005 \%$ dalam PBS yang mengandung hidrogen proksida $0.2 \%$ ). Obyek gelas selanjutnya dicuci dengan air kran dan diwarnai dengan perwarna Mayer's hematoxyline. Setelah dicuci dengan air kran, sel selanjutnya didehidrasi dengan alkohol, dibersihkan dengan xylol dan ditutup

Tabel 2 Hasil analisis statistik kadar glukosa darah sesudah diberikan ekstraks etanol Cordyceps militaris

\section{Deskriptif}

\begin{tabular}{|c|c|c|c|c|c|c|c|c|}
\hline \multirow[b]{2}{*}{ Glukosa } & \multirow[b]{2}{*}{$\mathbf{N}$} & \multirow[b]{2}{*}{ Mean } & \multirow{2}{*}{$\begin{array}{c}\text { Std. } \\
\text { Deviation }\end{array}$} & \multirow{2}{*}{$\begin{array}{l}\text { Std. } \\
\text { Error }\end{array}$} & \multicolumn{2}{|c|}{$\begin{array}{l}\text { 95\% Confidence Interval for } \\
\text { Mean }\end{array}$} & \multirow[b]{2}{*}{ Minimum } & \multirow[b]{2}{*}{ Maximum } \\
\hline & & & & & Lower Bound & Upper Bound & & \\
\hline Kontrol & 5 & 399.20 & 28.066 & 12.551 & 364.35 & 434.05 & 372 & 446 \\
\hline Ekstraks etanol Cordycepsmilitaris 50\% & 5 & 198.60 & 30.419 & 13.604 & 160.83 & 236.37 & 171 & 250 \\
\hline Ekstraks etanol Cordycepsmilitaris $100 \%$ & 5 & 141.00 & 17.073 & 7.635 & 119.80 & 162.20 & 121 & 168 \\
\hline Total & 15 & 246.27 & 117.025 & 30.216 & 181.46 & 311.07 & 121 & 446 \\
\hline
\end{tabular}




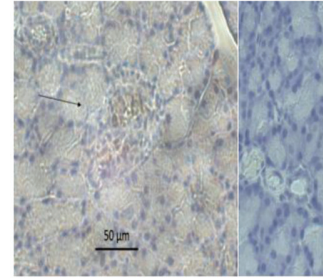

(a)

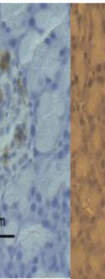

(b)

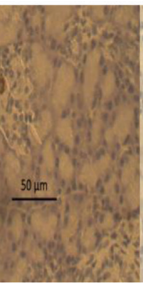

(c)

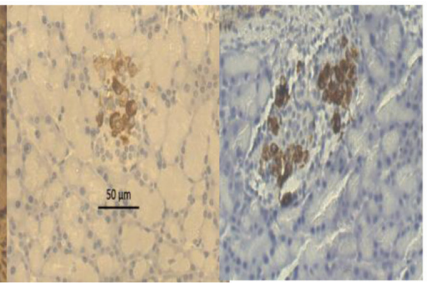

(e)

Gambar 1 Sel beta pankreas berwarna kecoklatan pada tikus kontrol 1 (a), Sel beta pankreas berwarna kecoklatan pada tikus kontrol 2 (b), Sel beta pankreas pada tikus kontrol 3 (c), Sel beta pankreas pada tikus perlakuan 1 nomer 1 (d) dan Sel beta pankreas pada tikus perlakuan I nomer 2 (e)

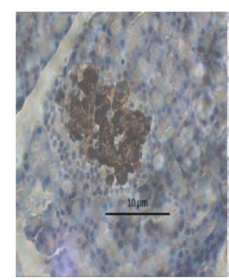

(a)

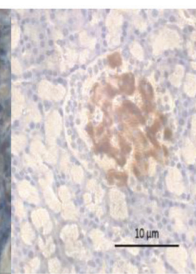

(b)

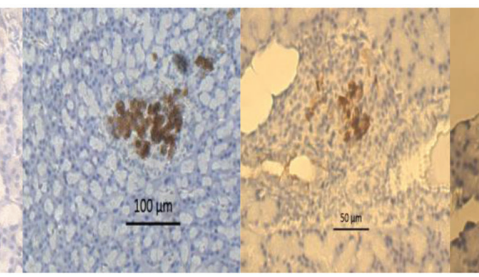

(c) (d)

lebih rendah jika dibandingkan dengan aktivitas antioksidan vitamin C (Won dan Park, 2004). Hasil penelitian Choi dkk, (2014) dan Shin, dkk (2009) menemukan hal yang sama, dan menyimpulkan bahwa efek tersebut disebabkan oleh Cordycepin yang menekan inflamasi meskipun melalui jalur yang berbeda yaitu supresi jalur aktivasi NFkB melalui TLR-4 dan supresi IL- $1 \beta$, TNF- $\alpha$.

Selain efek di atas, Cordycepin juga terbukti mampu menekan hiperglikemia sebesar $47 \%$ dan meningkatkan Oral Glucose Tolerance menurut hasil eksperimen pada hewan coba. ${ }^{8,9,13}$

Berdasarkan hasil penelitian pendahuluan pada 15 ekor tikus, yaitu masing-masing 5 ekor per kelompok, didapatkan bahwa rerata kadar glukosa darah pada kelompok kontrol adalah 399,20 $\pm 28,07 \mathrm{mg} / \mathrm{dl}$, rerata kadar glukosa darah kelompok perlakuan 1 (ekstraks etanol C. militaris 50\%) adalah $198,60 \pm 30,42 \mathrm{mg} / \mathrm{dl}$, dan, rerata kadar glukosa darah kelompok perlakuan 2 (ekstraks etanol C. militaris 100\%) adalah $141,00 \pm 17,03 \mathrm{mg} / \mathrm{dl}$. Dengan uji One Way Anova didapatkan bahwa nilai $p=0,001$. Hal ini menunjukkan bahwa terdapat perbedaan secara bermakna kadar glukosa darah sesudah diberikan ekstraks etanol C. militaris. Lebih lanjut diketahui bahwa pemberian ekstraks etanol C. militaris dapat menurunkan kadar glukosa darah sebesar 50, 25\% pada konsentrasi 50\% dan $64,68 \%$ pada konsentrasi $100 \%$.

Penelitian-penelitian telah menunjukkan adanya berbagai aktivitas farmakologis dari ekstrak C. militaris seperti imunomodulator, anti kanker/ tumor, antimetastatik, antiinflamasi, antioksidan, antimikrobial (bakteri, virus, jamur dan parasit), steroidogenik, antifatigue, antistres, efek hipoglikemik/anti diabetik, hipolipidemik, efek hipotensif dan vasorelaksan, liverprotektif, renoprotektif, pneumoprotektif, neuroprotektif dan antiaging. Karena itu perkembangan C. militaris sebagai salah satu obat herbal akan sangat penting dan bermanfaat bagi kesejahteraan manusia..$^{9-12}$

Volume sel beta pankreas dapat berfluktuasi sesuai kebutuhan tubuh terhadap hormon insulin demi mempertahankan homeostasis. Volume sel beta pankreas dapat meningkat pada ibu hamil atau pada pasien dengan insulin resisten di mana kebutuhan insulin meningkat. ${ }^{16}$ Seperti yang telah disebutkan di atas, peningkatan massa sel beta pankreas disebabkan oleh duplikasi dari sel beta pankreas yang sudah ada, atau disebut dengan Beta Cell Replication (BCR) dan proses neogenesis dari sel-sel progenitor yang ada dalam pankreas, atau disebut dengan Whole Islet Neogenesis (WIN).

Riset juga membuktikan bahwa sel beta pankreas memiliki kemampuan untuk beregenerasi spontan setelah mengalami ablasi hampir seluruhnya. Tikus yang menjalani prosedur pankreatektomi 
dan kehilangan 90\% massa pankreasnya, dapat mengalami regenerasi sel beta pankreas sampai mencapai $45 \%$ massa awalnya dalam 8 minggu. Sementara penelitian lain pada tikus menyebutkan bahwa tikus mampu sembuh spontan dari diabetes yang diinduksi dengan cara membunuh 70-80\% massa sel beta pankreasnya. ${ }^{9}$

Hasil pemeriksaan imunohistokimia dalam penelitian pendahuluan ini juga menunjukkan bahwa jumlah sel beta pankreas pada kelompok 1 dan 2 lebih banyak dari pada jumlah sel beta pankreas kelompok kontrol, terutama pada kelompok perlakuan 2 dengan konsentrasi ekstraks etanol C. militaris sebesar $100 \%$. Hal ini menunjukkan bahwa C. militaris tampaknya mampu menghambat penurunan massa sel beta pankreas pada tikus DM yang diinduksi dengan STZ dan NA.

\section{SIMPULAN}

Terdapat perbedaan secara bermakna kadar glukosa darah sesudah diberikan ekstraks etanol Cordyceps militaris. Lebih lanjut diketahui bahwa pemberian ekstraks etanol Cordyceps militaris dapat menurunkan kadar glukosa darah sebesar 50, 25\% pada konsentrasi 50\% dan 64, 68\% pada konsentrasi $100 \%$. C. militaris tampaknya dapat menghambat penurunan massa sel beta pankreas pada tikus DM yang diinduksi dengan STZ dan NA terutama pada konsentrasi $100 \%$.

\section{DAFTAR PUSTAKA}

1. Kahn, S., Hull, R. \& Utzschneider, K., Mechanisms linking obesity to insulin resistance and type 2 diabetes. Nature, 444. 2006

2. Biddinger, S. B. dan Emanuelli, B. Insulin Resistance in The Metabolic Syndrome. In: Ahima, R.S., editor. Metabolic Basis of Obesity, 1st Ed. USA: Springer. p. 175-198. 2011.

3. Leonardi, O., Mints, G. dan Hussain, M., Beta-cell apoptosis in the Pathogenesis of Human Type 2 Diabetes Mellitus. European Journal of Endocrinology, 149: 99-102. 2003.

4. Godoy-Matos, A. F. The Role of Glucagon on Type 2 Diabetes At a Glance. Diabetology \& Metabolic Syndrome, 6: 91-95. 2014.
5. Nahas, RType 2 Diabetes. In: Rakel, D., editor. Integrative Medicine, 3rd Ed. USA: Elsevier. p. 297-311. . 2012.

6. Chan, J. \& Abrahamson, M. Pharmacological Management of Type 2 Mellitus: Rationale for Rational Use of Insulin. Mayo Clinic Proceedings, 78: 459-467. 2003.

7. Cohen, A. dan Horton, E.S. Progress in The Treatment of Type 2 Diabetes, New Pharmacologic Approaches to Improve Glycemic Control. Current Medical Research and Opinion, 23 (4): 905-917. 2007.

8. Choi, S., Park, C., Choi, M., Jun, D., dan Park, S. Improvement of Insulin Resistance and Insulin Secretion by Water Extracts of Cordyceps militaris, Phellinus linteus, and Paecilomyces tenuipes in $90 \%$ Pancreatectomized. Bioscience, Biotechnology and Biochemistry, 68(11): $2257-$ 2264. 2004.

9. Won, S. \& Park, E., Anti-inflammatory and Related Pharmacological Activities of Cultured Mycelia and Fruiting Bodies of CordycepsMilitaris. Journal of Ethnopharmacology, 96: 555-561. 2004.

10. Das, S.K, Masuda, M., Sakurai, A. dan Sakakibara,M. Medicinal Uses of The Mushroom Cordyceps Militaris, Current State And Prospects. Elsevier Fitoterapia, 81: 961-968. 2010.

11. Paterson, R., Cordyceps - A traditional Chinese Medicine and Another Fungal Therapeutic Biofactory. Elsevier Phytochemistry, 69: 1469-1495. 2008.

12. Rao, Y., Fang, S. H., Wu, W. S., dan Tzeng, Y. M. Constituents Isolated From Cordyceps Militaris Suppress Enhanced Inflammatory Mediator's Production. ElsevierEthnophrarmacology, 131: 363-367. 2010.

13. Shin, S., Lee, S., Kwon, J., Moon, S., Lee, S., Lee, C., Cho, K., Ha, N., \& Kim, K. Cordycepin Suppresses Expression of Diabetes Regulating Genes by Inhibition of Lipopolysaccharide-induced Inflammation in Macrophages. Immune Network, 9(3): 98-105. 2009.

14. Machin, D dan Campbell, MJ. Design of Studies for Medical Research. John Wiley \& Sons, Chichester. 2005.

15. Kazemeini SK, Emtiazy M, Mosavat SH, Rahmanian M, Lotfi MH, Owlia F, Khivah A. The efficacy of the diet therapy based on Traditional Persian Medicine on blood glucose and lipid profile in adults with type 2 diabetes mellitus patients: A Randomized Controlled Clinical Trial. Bali Medical Journal. 2017 Jan 1;6(1):192-7.

16. Khalaileh A, Gonen-Gross T, Magenheim J, Nir T, Porat S, Salpeter S, Stolovich-Rain M, Swisa A, Weinberg N, Dor Y. Determinants of pancreatic $\beta$-cell regeneration. Diabetes, Obesity and Metabolism. 2008 Nov 1;10(s4):128-35.

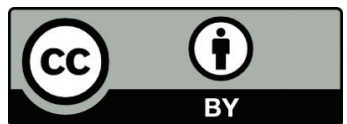

This work is licensed under a Creative Commons Attribution 